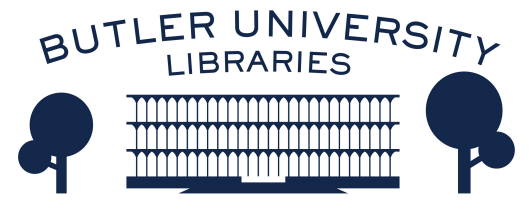

\title{
Journal of Hindu-Christian Studies
}

\section{Book Review: The Future of Hindu-Christian Studies: A Theological Inquiry}

Arvind Sharma

McGill University

Follow this and additional works at: https://digitalcommons.butler.edu/jhcs

Part of the Christianity Commons, Hindu Studies Commons, and the Religious Thought, Theology and Philosophy of Religion Commons

\section{Recommended Citation}

Sharma, Arvind (2017) "Book Review: The Future of Hindu-Christian Studies: A Theological Inquiry," Journal of Hindu-Christian Studies: Vol. 30, Article 29.

Available at: https://doi.org/10.7825/2164-6279.1681

The Journal of Hindu-Christian Studies is a publication of the Society for Hindu-Christian Studies. The digital version is made available by Digital Commons @ Butler University. For questions about the Journal or the Society, please contact cbauman@butler.edu. For more information about Digital Commons @ Butler University, please contact digitalscholarship@butler.edu. 
religious conflict and the realization of "communal harmony." Drawing in a special way from his study of the Mandaikadu religious conflicts in the Kanyakumari district (1982), Swamy contests this claim. It ignores the fact that the so-called "religious violence" almost always has social and economic roots and overlooks "the political intervention which plays with the religious identities of the people in order to boost vote-bank politics" (p. 8).

My argument is that it is not the misunderstanding of religion or the political use of religion that are solely responsible for religious conflicts. Rather, it is the naming conflicts among individuals and groups, who live with multiple religious identities, as religious for vested interests that is crucial. The dialogue promoters seldom recognize this when talking about either religions causing conflict or religious people being instruments in the hands of politicians creating conflicts (p. 121).

We need more focus on the vested interests who benefit when a conflict with socioeconomic causes is labeled "religious."

The third limitation of dialogue in India discussed by Swamy has to do with what he regards at its elite nature and methods. The consequence is that the grassroots are "silent objects" of these conversations. The reality of their living relationships is ignored and there is little interest in learning from the life experiences in local communities. Elite dialogue is a top-down process that ignores the fact of multiple identities among the common people.

The problems of interreligious dialogue that Swamy discusses in this work (the construction of religion/religions and fixed identities; the understanding of conflict as religious and elitism) are not unknown observations. The special contribution of this study is the challenge of these assumptions about dialogue by his empirical work at the ground level. He successful demonstrates the fluidity and complexity of relationships and the ways in which such relationships may be more successful in overcoming communal tensions and conflicts. This dimension of Swamy's work grants it a relevance that goes beyond the Indian context. Interreligious dialogue is certainly diminished when it is isolated and disconnected from relations obtaining among human beings in community. Theories about dialogue need the interrogation and critique of practice. This book is a welcome addition to critical literature on interreligious dialogue and makes a strong case for more studies that are empirically based.

Anantanand Rambachan

Saint Olaf College

\section{The Future of Hindu-Christian Studies: A Theological Inquiry. By Francis X. Clooney, S.J. London and New York: Routledge, 2017, xi + 135 pages.}

THIS book consists of what are known as the Westcott-Teape Memorial Lectures (after the names of the person in whose honor the lectures were endowed and the donor) delivered by
Professor Francis X. Clooney, SJ, of Harvard Divinity School at Delhi, Kolkata, and Chennai in India and at the University of Cambridge in U.K. during 2015-16. This lecture series, starting in 
1955, is dedicated to the theme of promoting Hindu-Christian understanding. It is gratifying to see that this latest set of lectures did not take long to assume the form of a book, which possesses many merits apart from its timely appearance. The fact that they are delivered by Professor Clooney, who has devoted a life time to the pursuit of such understanding, renders them all the more valuable. His words carry weight.

The concept of Hindu-Christian understanding, though valuable, is vague but Professor Clooney gives it definite form by first reviewing the history of the Jesuit study of Hinduism, then the study of Christianity by Hindu academics, and finally by proposing a theological "third space", that is to say, "a mode of study that is essentially faith-grounded and community-grounded, and yet always deeply dialogical as well" (p. 17), as a way of moving beyond the problems to which any such exercise is vulnerable. The proposal is made in full awareness of the controversies currently clouding the academic study of religion such as the insider/outsider debate, the theology/religious studies debate, and the social sciences/humanities debate. According to Professor Clooney it is "this kind of religious studies, open to theological concerns even if not fully guided by the faith concerns of theology, that is required for Hindu-Christian studies to be a viable field today" (p. 98).

Professor Clooney has, in my view, succeeded in making a case for Hindu-Christian Studies as "a fundamentally theological project irreducible to historical investigations or ethnographic writing, or to the immediate possibilities and obligations of dialogue" ( $p$. 123). And if I were to view his proposal from a Hindu perspective, then I would have to add that not only has he succeeded in making the case but has done so admirably. Professor Clooney breaks new ground when his proposal is viewed from a Hindu perspective. In the course of India's intellectual encounter with the West, Indian intellectuals proceeded by engaging Western philosophy rather than Christian theology as their main vis-a-vis in this encounter, even though to this day Indians complain of the step-motherly treatment they receive at the hands of Western philosophy. Many reasons could be offered to explain why Hindu thinkers chose to engage Western philosophy in preference to Christian theology but surely one motive was to appear more 'rational' in the eyes of the conquering West. Advaitic philosophy offered the triumphalist temptation of upstaging Christian theism by arguing that the philosophical monism that Advaita Vedanta stood for represented a higher state of religio-spiritual evolution, thereby hoisting the West by its own evolutionary petard. Although this achievement came at the cost of exposing the foundational beliefs of one's religion to philosophical skepticism, the temptation was just too great to resist. One consequence of this development, however, has been the etiolation of Hindu theology.

Thus although both Western philosophy and Christian theology appeared on the horizon as offering the opportunity of engagement around the same time, namely the beginning of the nineteenth century, Hindu intellectuals, by and large opted for philosophy over theology. Perhaps one factor in this was also the triumphalism inherent in the Christian theology of the period represented by the claim that Christianity was the crown of Hinduism. This reality has now changed in the post-colonial age, which favors a dialogical rather than a 
triumphalist approach from either side. Hindu scholars might wish to consider the fact that theology proceeds by accepting the basic faith stance of a tradition while philosophy begins by questioning it, and the study of religion by leaving that option open. Developing Hindu theology might be one way of combating the misrepresentation of Hinduism which some of them and members of the Hindu community have been so loudly and even vehemently complaining about. That convergence of Christian and Hindu theology is an exciting prospect as has already been demonstrated by the work of such scholars as Anantanand Rambachan and Rita Sherma.

There is an obstacle, however, in the way of the realization of this ideal-namely, the Hindu fear of Christian proselytization. The issue is recognized by Professor Clooney (pp. 44, 49, 104, 107 , etc.) but I would like to emphasize it, as it is often the elephant in the room when Hindus and Christians sit down at the same table. Even Mahatma Gandhi had to overcome his 'dislike' for Christianity in this respect before he could engage it in dialogue. Two points need to be clearly recognized in this connection by both the parties. The first is that even when conversion is disavowed as the overt or covert goal of such a theological engagement between the Hindus and the Christians, it will have to be admitted, as Professor Clooney himself notes (pp. 104, 107), that conversion is nevertheless a possible outcome of such an undertaking, even if not the intended one. Such a possibility cannot be foreclosed in any genuine dialogue. It has to be recognized, however, that such conversion is very different from the kind feared by most Hindus. The second is that the issue of conversion will never go away because the divergence between Hinduism and
Christianity on this point represents a clash between two orientations both of which are deeply lodged in human nature. If, for instance, one were to discover the secret of life or crack the riddle of existence, and genuinely felt so (as a Christian might) then will one not feel compelled to share with it others? On the other hand, what could be more natural than for the other person to say, "No, thanks. I am not interested" or to even claim that one has one's own answer to this riddle which one regards as equally if not more authentic. Such a realization leads to an interesting conclusion, that the controversy over conversion can never be finally solved; it will have to be constantly engaged and negotiated.

I conclude with a comment and a question. The comment pertains to the interface of Professor Clooney's proposal with contemplative studies. It would be instructive to bring Professor Clooney's proposal in relation to the current trend towards contemplative studies, if for no other reason than for the focus on interiority common to both. When one does so one realizes that in the case of the contemplative studies, it is the interiority of us as human beings which is engaged, while in the case of the proposal made by Professor Clooney it is the interiority of the believers which is addressed.

The question pertains to the interface of Professor Clooney's proposal with the phenomenology of religion. Let us imagine that a Christian puts on the wooden sandals of the Hindu and begins to talk his walk. That is to say, starts doing Hindu theology as a Hindu, all the while remaining a Christian. And the Hindu puts on the boots of the Christian, and starts doing Christian theology as a Christian, all the while remaining a Hindu. Is this an equally viable way 
154 Book Reviews

of doing Hindu-Christian theology compared to

Arvind Sharma

Professor Clooney's suggestion?

McGill University 